\title{
Succinate dehydrogenase functioning by a reverse redox loop mechanism and fumarate reductase in sulphate-reducing bacteria
}

\author{
Tanja Zaunmüller, ${ }^{1}$ David J. Kelly, ${ }^{2}$ Frank O. Glöckner ${ }^{3}$ \\ and Gottfried Unden ${ }^{1}$ \\ ${ }^{1}$ Institut für Mikrobiologie und Weinforschung, Johannes Gutenberg Universität Mainz, \\ 55099 Mainz, Germany \\ ${ }^{2}$ Department of Molecular Biology and Biotechnology, University of Sheffield, Western Bank, \\ Sheffield S10 2TN, UK \\ ${ }^{3} \mathrm{MPI}$ für Marine Mikrobiologie, Celsiusstr. 1, 28359 Bremen, Germany
}

Correspondence

Gottfried Unden

unden@uni-mainz.de

Received 16 January 2006

Revised 13 April 2006

Accepted 25 April 2006
Sulphate- or sulphur-reducing bacteria with known or draft genome sequences (Desulfovibrio vulgaris, Desulfovibrio desulfuricans G20, Desulfobacterium autotrophicum [draft], Desulfotalea psychrophila and Geobacter sulfurreducens) all contain sdhCAB or frdCAB gene clusters encoding succinate : quinone oxidoreductases. $f r d D$ or $s d h D$ genes are missing. The presence and function of succinate dehydrogenase versus fumarate reductase was studied. Desulfovibrio desulfuricans (strain Essex 6) grew by fumarate respiration or by fumarate disproportionation, and contained fumarate reductase activity. Desulfovibrio vulgaris lacked fumarate respiration and contained succinate dehydrogenase activity. Succinate oxidation by the menaquinone analogue 2,3-dimethyl-1,4-naphthoquinone depended on a proton potential, and the activity was lost after degradation of the proton potential. The membrane anchor SdhC contains four conserved His residues which are known as the ligands for two haem $B$ residues. The properties are very similar to succinate dehydrogenase of the Gram-positive (menaquinone-containing) Bacillus subtilis, which uses a reverse redox loop mechanism in succinate : menaquinone reduction. It is concluded that succinate dehydrogenases from menaquinone-containing bacteria generally require a proton potential to drive the endergonic succinate oxidation. Sequence comparison shows that the SdhC subunit of this type lacks a Glu residue in transmembrane helix IV, which is part of the uncoupling E-pathway in most non-electrogenic FrdABC enzymes.

\section{INTRODUCTION}

Succinate: quinone oxidoreductases (SQR) from bacteria function either as succinate: quinone reductase (succinate dehydrogenase, or Sdh) in succinate oxidation, or as quinol: fumarate reductase (fumarate reductase, or Frd) in fumarate respiration (Hederstedt 2002; Kröger et al., 2002; Cecchini et al., 2002). Bacillus subtilis, which contains menaquinone as the only respiratory quinone, has been shown to contain a specific type of succinate dehydrogenase (Schirawski \& Unden, 1998; Schnorpfeil et al., 2001). In contrast to the classical succinate dehydrogenase consisting of four subunits (SdhABCD), the enzyme from B. subtilis is

\footnotetext{
Abbreviations: BV; reduced benzyl viologen; CCCP, carbonyl cyanide $m$-chlorophenylhydrazone; DCPIP, dichlorophenol indophenol; DMN, 2,3-dimethyl-1,4-naphthoquinone; TRAP, tripartite ATP-independent periplasmic.

The GenBank/EMBL/DDBJ accession number for the sequence reported in this paper is D0643793.
}

composed of three subunits (SdhABC). Catalytic subunit A and the $\mathrm{Fe}-\mathrm{S}$ cluster subunit $\mathrm{B}$ are exposed to the cytoplasm. Subunit $\mathrm{C}$ serves as the membrane anchor and contains the active site for menaquinone reduction. SdhC of the $B$. subtilis enzyme carries two haem B molecules in a transmembrane arrangement: one of the haem $\mathrm{B}$ molecules is close to the outer, the other to the inner aspect of the membrane (Hägerhäll \& Hederstedt 1996; Hägerhäll et al., 1995; Körtner et al., 1990; Lancaster et al., 1999; Simon et al., 1998). The haem B molecules are bound by four conserved His residues.

Succinate oxidation by menaquinone is endergonic, since succinate $\left(E_{0}=+30 \mathrm{mV}\right)$ is more electropositive than the acceptor menaquinone $\left(E_{0}=-80 \mathrm{mV}\right)$. The reaction requires a transmembrane $\mathrm{H}^{+}$-potential $(\Delta \mathrm{p})$ for function (Schirawski \& Unden, 1998). Succinate oxidation (succinate $\rightarrow$ fumarate $+2 \mathrm{H}^{+}+2 \mathrm{e}^{-}$) takes place in the cytoplasm, whereas menaquinone reduction $\left(\mathrm{MK}+2 \mathrm{H}^{+}+\right.$ $\left.2 \mathrm{e}^{-} \rightarrow \mathrm{MKH}_{2}\right)$ is believed to occur close to the outer 
aspect of the membrane (Schirawski \& Unden, 1998). An active site for menaquinone close to the outer aspect is supported by the presence of a conserved Glu residue which is homologous to Glu66 in subunit FrdC of Wolinella succinogenes fumarate reductase. This residue is at the active site for menaquinol oxidation (Lancaster et al., 2000). Location of the oxidative and reductive half-reactions on opposite sides of the membrane requires a transmembrane electron transfer, which is effected by the two haem B molecules in subunit $\mathrm{C}$. The overall reaction according to this scheme consumes and releases protons on opposite sides of the membrane, and the enzyme functions by a reverse $(\Delta \mathrm{p}-$ driven) redox loop mechanism (Schirawski \& Unden, 1998). Sdh of this type is active only in intact (energized) cells, and is inactivated by addition of an uncoupler, or in membrane preparations (Lemma et al., 1990; Schirawski \& Unden 1998; Schnorpfeil et al., 2001). The reaction of ubiquinone $\left(E_{0}=+110 \mathrm{mV}\right)$-dependent succinate dehydrogenase, on the other hand, is exergonic. Bacterial and mitochondrial enzymes of this type retain activity with the quinones in the presence of uncouplers and in membrane preparations, and contain only one haem (with two conserved His residues) close to the inner aspect of the membrane. In addition, the membrane anchor consists of two subunits (subunits CD) which are smaller in size (for an overview see Hägerhäll, 1997; Lancaster, 2002b).

Sulphate-reducing bacteria contain only menaquinone as the respiratory quinone (Collins \& Widdel, 1986). The anaerobic Gram-negative bacteria are physiologically and phylogenetically largely distant from the (facultatively) aerobic Grampositive genus Bacillus, raising the question whether succinate dehydrogenase is of the same type as in the genus Bacillus. Genomic sequences of several sulphate- and sulphurreducing bacteria are available, and the genomes contain gene clusters similar to the $s d h C A B$ genes of $B$. subtilis. The gene cluster is similar to the frd $C A B$ genes encoding fumarate reductase in W. succinogenes (see Kröger et al., 2002, Lancaster \& Simon, 2002 for a review). Fumarate reductase from $W$. succinogenes is a three-subunit enzyme (FrdABC) and catalyses fumarate reduction by menaquinol (Unden et al., 1980; Kröger et al., 2002; Biel et al., 2002). FrdC of W. succinogenes carries two haem $B$ molecules with a transmembrane arrangement similar to SdhC of B. subtilis (Körtner et al., 1990; Simon et al., 1998). The SdhABC and FrdABC enzymes are similar in sequence and identical in the prosthetic groups.

To identify the role of the enzymes encoded by the $s d h / f r d$ genes, their function was determined for selected strains. Desulfovibrio desulfuricans (strain Essex 6) used the enzyme for fumarate respiration and a new form of fumarate disproportionation. In Desulfovibrio vulgaris on the other hand, the enzyme functions as succinate dehydrogenase. Succinate dehydrogenase of $D$. vulgaris had characteristic properties of the $B$. subtilis succinate dehydrogenase and required the proton potential for function, which appears to be a general property of menaquinone-dependent succinate dehydrogenases.

\section{METHODS}

Bacteria and growth. Desulfovibrio desulfuricans (strain Essex 6, DSMZ no. 642) and Desulfovibrio vulgaris (strain Hildenborough, DSMZ no. 644) were used. Subcultures of the bacteria were grown in modified Desulfovibrio medium 63 plus lactate (DSM, 1993) in Sovirell tubes under an atmosphere of $\mathrm{N}_{2}$ at $37^{\circ} \mathrm{C}$. Modified medium 63 consists of $0.5 \mathrm{~g} \mathrm{~K}_{2} \mathrm{HPO}_{4} \mathrm{l}^{-1}, 1 \cdot 0 \mathrm{~g} \mathrm{NH}_{4} \mathrm{Cl} \mathrm{l}^{-1}, 0 \cdot 1 \mathrm{~g}$ $\mathrm{CaCl}_{2} \cdot 2 \mathrm{H}_{2} \mathrm{O} \mathrm{l}^{-1}, 1.0 \mathrm{~g}$ yeast extract $1^{-1}$ (Serva no. 24540 ), $1.0 \mathrm{mg}$ resazurin $1^{-1}, 0.6 \mathrm{~g}$ trisodium citrate $1^{-1}, 50 \mathrm{mg}$ EDTA $1^{-1}, 2.5 \mathrm{mg}$ $\mathrm{FeSO}_{4} \cdot 7 \mathrm{H}_{2} \mathrm{O} 1^{-1}, 0 \cdot 1 \mathrm{~g}$ sodium thioglycolate $1^{-1}$ and $0 \cdot 1 \mathrm{~g}$ ascorbic acid $1^{-1}$ at $\mathrm{pH} 7 \cdot 8$. Sterile medium $(400 \mathrm{ml})$ in infusion bottles $(500 \mathrm{ml})$ was made anoxic by repeated degassing under vacuum and gassing with $\mathrm{N}_{2}$ before inoculation. For growth on sulphate, the medium contained in addition sulphate $(25 \mathrm{mM}$ disodium sulphate, $25 \mathrm{mM}$ magnesium sulphate) plus lactate $(50 \mathrm{mM}$ sodium DLlactate) or succinate $(50 \mathrm{mM}$ disodium succinate) as indicated in the individual experiments. For growth on fumarate or formate + fumarate $(50 \mathrm{mM}$ disodium fumarate without or with $50 \mathrm{mM}$ sodium formate), the disodium/magnesium sulphate was replaced by $17 \mathrm{mM} \mathrm{NaCl}$ and $21 \mathrm{mM} \mathrm{MgCl}_{2}$. The media $(400 \mathrm{ml}$ ) were inoculated with $7 \mathrm{ml}$ of a subculture grown with lactate plus sulphate for $24 \mathrm{~h}$, and incubated for about $24 \mathrm{~h}$.

Cell suspensions and cell-free extract for measurement of enzyme activities. The bacteria were sedimented from the growth media by centrifugation for $30 \mathrm{~min}$ at $10000 \mathrm{~g}$, and washed three times with anoxic potassium phosphate $(50 \mathrm{mM}$ at $\mathrm{pH} 7 \cdot 8)$. To prepare the cell suspension, the bacteria were suspended in the same buffer at $400 \mathrm{mg}$ wet weight of bacteria per l. For preparing the cellfree extract, the sedimented and washed bacteria $(100 \mathrm{mg}$ wet weight) were mixed with $180 \mu \mathrm{l}$ of the same buffer and $0.5 \mathrm{~g}$ glass beads $(0.13 \mathrm{~mm}$ in diameter, Zirkonia-silica, Roth). The suspension was swirled rapidly on a mixer for $30 \mathrm{~s}$ followed by incubation on ice for $5 \mathrm{~min}$. The procedure was repeated six times; the debris and glass beads were sedimented by centrifugation. The glass beads were extracted once with the anoxic buffer, centrifuged, and the supernatants were combined.

Enzyme activities. Fumarate reductase was measured with reduced benzylviologen $\left(\mathrm{BV}^{*}\right)$ as the electron donor (Lemma et al., 1990; Schirawski \& Unden, 1998; Schnorpfeil et al., 2001). Measurement of succinate dehydrogenase activity with the dye dichlorophenol indophenol (DCPIP) or the menaquinone analogue 2,3-dimethyl1,4-naphthoquinone (DMN) was as described previously (Schirawski \& Unden, 1998; Schnorpfeil et al., 2001). All enzyme tests were performed at $37^{\circ} \mathrm{C}$ under anoxic conditions in cuvettes sealed with rubber stoppers, and 1 unit corresponds to the consumption of $1 \mu \mathrm{mol}$ fumarate or succinate $\min ^{-1}$ (g protein) ${ }^{-1}$. Protein concentrations of cell suspensions were determined by the biuret method with KCN (Bode et al., 1968), and those of cell-free extracts by the Bradford assay (Bradford, 1976). The uncoupler CCCP (carbonyl cyanide $m$-chlorophenylhydrazone, $10 \mu \mathrm{M}$ final concentration, stock solution $1 \mathrm{mM}$ in ethanol) was added as indicated.

Fumarate disproportionation in cell suspensions and growing bacteria. $D$. vulgaris and $D$. desulfuricans were grown in modified medium 63 with lactate + sulphate and harvested in the late exponential growth phase. Cells were sedimented by centrifugation, washed twice and resuspended at $\mathrm{OD}_{578} 8-10$ in anoxic MOPS buffer $(100 \mathrm{mM}, \mathrm{pH} 7 \cdot 8)$. Cells were transferred into rubberstoppered bottles and degassed and gassed by $\mathrm{N}_{2}$ for three cycles. Growth was started by the addition of anoxic fumarate solution ( $5 \mathrm{mM}$ final concn). Samples were withdrawn by syringes as required and centrifuged at $10000 \mathrm{~g}$ for $5 \mathrm{~min}$. The supernatants were used for HPLC analysis of the substrates and of the fermentation products (Richter et al., 2001). 
For measurement of the products of fumarate disproportionation by growing bacteria, samples were withdrawn from the anaerobic cultures in the serum bottles. After removal of bacteria and particles by centrifugation, the medium or buffer was used for quantitative measurement of the substrates and products by HPLC using a Aminex HPX 87H column (Richter et al., 2001).

Amplification of the sdhC fragment of $D$. desulfuricans (strain Essex 6). For amplification of $s d h C$, genomic DNA of $D$. desulfuricans (Essex 6) was amplified with primers CGCAAGATGCCCTTCCGCA and TCG GAN CCT TTG ACS GTR TC $(\mathrm{N}=$ $\mathrm{A} / \mathrm{C} / \mathrm{G} / \mathrm{T}, \mathrm{S}=\mathrm{G} / \mathrm{C} ; \mathrm{R}=\mathrm{A} / \mathrm{G})$. The primers are derived from the sequences of SdhC of $D$. desulfuricans $\mathrm{G} 20$ and D. vulgaris encoding the predicted loop between transmembrane helices 2 and 3 , and from a conserved sequence in SdhA of D. desulfuricans G20, D. vulgaris and Desulfobacterium autotrophicum. PCR products of the expected size (645 bp) were amplified in a second step using the same primers and sequenced after purification.

Phylogenetic analysis of protein sequences. Sequences of TRAP genes were obtained from the ERGO (Overbeek et al., 2003), NCBI and UniProt databases. The contigs from the Rhodobacter capsulatus genome sequence were analysed using the Artemis package (Berriman \& Rutherford, 2003). For phylogenetic analyses, sequences were aligned in CLUSTAL X (Thompson et al., 1997) and the output file used in PHYLIP (Felsenstein, 1989) to produce a bootstrapped distance matrix tree, which was viewed in TREEVIEW (Page, 1996).

\section{RESULTS}

\section{sdhCAB/frdCAB gene clusters in sulphate- reducing bacteria and properties of subunit $C$}

Genomic sequences from sulphate- and sulphur-reducing bacteria (Desulfovibrio vulgaris, Desulfovibrio desulfuricans G20, Desulfobacterium autotrophicum, Desulfotalea psychrophila and Geobacter sulfurreducens) were screened for the presence of $s d h$ or frd genes (http://www.jgi.doe.gov/; www.tigr.org/; http://www.regx.de/m_status.php). Each of the genomes contained one copy of a $s d h / f r d C A B$ gene cluster. The clusters contained no $s d h D / f r d D$ genes, and the predicted SdhC or FrdC proteins were of a size (23 to $30 \mathrm{kDa}$ ) characteristic for $\mathrm{Sdh} / \mathrm{FrdC}$ proteins from enzymes lacking subunit D. Sdh/FrdC proteins from enzymes containing $\mathrm{SdhD} / \mathrm{FrdD}$ in addition, are distinctly smaller (13 to $18 \mathrm{kDa}$, respectively) (Hägerhäll, 1997).

The proteins encoded by the $s d h A / f r d A$ and $s d h B / f r d B$ homologues showed 27 to $66 \%$ sequence identity for subunit $\mathrm{A}$, and 22 to $61 \%$ identity for subunit $\mathrm{B}$ to the corresponding subunits of the B. subtilis and W. succinogenes enzymes. The FAD-binding sites in subunit $\mathrm{A}$ and the cysteine clusters in subunit $\mathrm{B}$ which bind the Fe-S clusters were conserved. The sequences allowed no prediction whether the enzyme from the sulphate-reducing bacteria represents Frd or Sdh. The SdhC/FrdC-subunits show a lower degree of sequence identity to FrdC of W. succinogenes ( $15 \cdot 4$ to $44 \cdot 9 \%$ identical residues), and to SdhC of B. subtilis ( $18 \cdot 3$ to $24 \cdot 8 \%$ identical residues) (Fig. 1). By the TMHMM program (www. cbs.dtu.dk/services/TMHMM/) five transmembrane helices are predicted for the $\mathrm{C}$ subunits, similar to the corresponding proteins from B. subtilis and W. succinogenes (Hägerhäll et al., 1995; Gross et al., 1998, Lancaster, 2002b; Lancaster \& Simon, 2002; Hägerhäll, 1997). The four His ligands for the haem B molecules in Sdh/FrdC of B. subtilis and W. succinogenes are conserved in subunits $C$ of the sulphate-reducing bacteria, suggesting a similar structure and topology. Some of the subunits contain also a Glu residue which is homologous to Glu180 of the E-pathway in the FrdC subunit of W. succinogenes (Lancaster, 2002a). D. desulfuricans strain G20, for which the genomic sequence is available, is not closely related to strain Essex 6, which was used for the physiological and biochemical experiments (Pires et al., 2003). Therefore the sequence of part of FrdC from $D$. desulfuricans (Essex 6) was determined (Fig. 1). The sequence comprised the fragment with the third and fourth of the His residues which represent one of the ligands to each of the two haem B groups (Hägerhäll \& Hederstedt, 1996; Simon et al., 1998). It can be concluded that both haem groups are present in FrdC of $D$. desulfuricans (strain Essex). The Glu residue homologous to Glu180 from the E-pathway, however, was not conserved. Glu66 of $W$. succinogenes, which is at the menaquinone/menaquinol site close to the outer aspect of the membrane (Lancaster et al., 2000), is found in all SdhC/FrdC sequences of the sulphate-reducing bacteria. The gene and sequence properties therefore suggest that the sulphate and sulphur reducers contain Sdh or Frd enzymes of the SdhABC or FrdABC type.

\section{Growth of sulphate reducers by fumarate respiration versus succinate oxidation}

It is not possible to decide from the sequence whether the enzymes encoded by $s d h / f r d$ function as succinate dehydrogenases or as fumarate reductases in vivo. Growth by fumarate respiration and succinate production on the other hand is a direct indication of the presence of fumarate reductase. To differentiate between the two types of enzymes, D. desulfuricans (strain Essex 6) and D. vulgaris were tested for growth with fumarate as an electron acceptor versus succinate as an electron donor in sulphate respiration (Fig. 2, Table 1). D. desulfuricans (Essex 6) was able to grow on fumarate when $\mathrm{H}_{2}$ or formate were supplied as electron donors at rates comparable to growth on sulphate. Succinate on the other hand stimulated growth on sulphate only marginally. $D$. vulgaris showed the best growth on lactate plus sulphate, whereas growth on fumarate was very low. The growth experiments therefore suggest that the enzyme of $D$. desulfuricans (Essex 6) functions as fumarate reductase, and that of $D$. vulgaris as succinate dehydrogenase.

The growth yields of $D$. desulfuricans (strain Essex 6) by fumarate respiration with formate or $\mathrm{H}_{2}$ were close to $5 \mathrm{~g}$ dry weight per mol fumarate (Table 1), corresponding to approx. $0.5 \mathrm{ATP} /$ fumarate, which is comparable to the growth yield by fumarate respiration of Escherichia coli and W. succinogenes (Kröger et al., 2002; Mell et al., 1982; Bernhard \& Gottschalk, 1978).

The major product of fumarate respiration was succinate, but in addition acetate (and $\mathrm{CO}_{2}$ ) were produced (Table 2). 


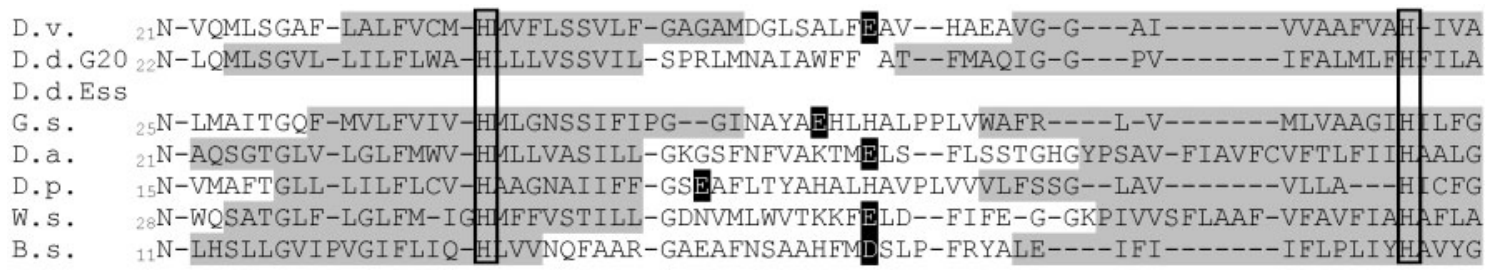

\begin{tabular}{|c|c|c|}
\hline $\begin{array}{l}\text { D.v. } \\
\text { D.d.G20 }\end{array}$ & $\begin{array}{l}\text { VGRKIPERMAES IVMYRHARLLHHADT--WRWVVQVLTALVLLLMVTV } \\
\text {-GRKMP FRTTEQRAFLRHAGMLRHKDT--WMWVAQVVTALI I LVMAS I }\end{array}$ & $\begin{array}{l}\text { IWEG-FMV-MPVAAGT-- } \\
\text { IYE--VLTDLPITAQK-. }\end{array}$ \\
\hline D.d.Ess & RANELGVFVQHSKGLKEVDT--WLWLVQVFTAIVILAGAFYH & IYS--VMTDLPINVAG--SAK-R--L-HS-- \\
\hline G.s. & --IQLSLENRAANPDT-YAVK-NYKKAT-MGSLSMLYTGLLLLSFI I YH & ILH--FTIRATPDIKLGVDSLGRFDVFGMVT \\
\hline D.a. & -VRKFPITWKQHT I IRSQMGMMNHGDTNLWYW--QVVTGF IMFFLGSYH & FFI--MLT-HPGQIDPYLSSD-R--VFS--- \\
\hline D.p. & --LYLFFENRTES-DSRYAVSVRTVKYS-LASKTMHWSGLFIFLFLI H & AV--FTFGGK-DIP--ISTLVE-ERLG--- \\
\hline .s. & -MRKFPINYRQYLTFKTHKDLMRHGDTTLW-WI-QAMTGFAMFFLGSYH & YI--MMT-QPQTIGP-VSSSFR--MVS \\
\hline s. & --VYIAFTAKNNA--GQYSYM-RN- & ] JWETRIAAQMGAEVN--FDMMAN-- \\
\hline
\end{tabular}

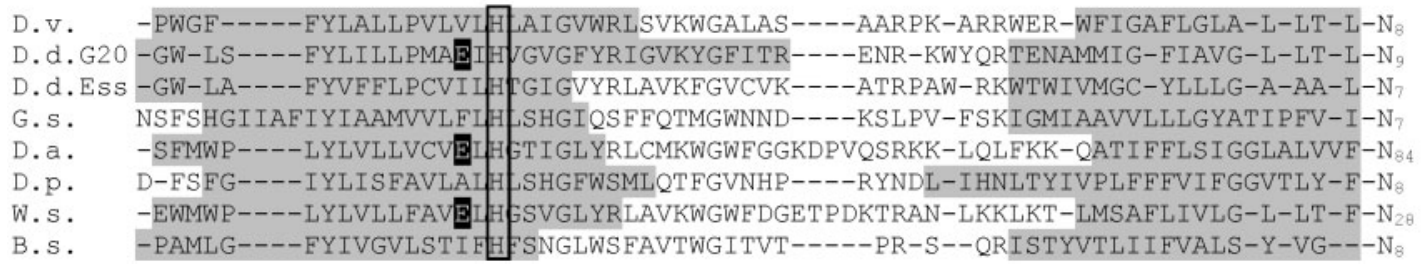

Fig. 1. Alignment of FrdC/SdhC sequences of sulphate-reducing bacteria, Wolinella succinogenes and Bacillus subtilis. The conserved His residues ( $\mathrm{H}$, supposed haem-binding sites) and the Glu (E) residues corresponding to E66 of $W$. succinogenes and $B$. subtilis, and to E180 of W. succinogenes, are boxed and outlined in black, respectively. Transmembrane helices predicted by the TMHMM program (http://www.cbs.dtu.dk/services/TMHMM) are marked in grey. The sequences were compared by CLUSTAL $\mathrm{W}$ in the protein database ExPASy (http://www.ebi.ac.uk/clustalw/index.html). The alignment contains 9 residues identical to all sequences, 23 conserved and 15 semiconserved substitutions according to CLUSTAL W (matrix, blosum; gap open, 1; gap extension, 0.05; end gaps, 10; other settings, default). B.s., B. subtilis (NCBI accession number CAB14805), D.v., Desulfovibrio vulgaris (AE017285); D.d., Desulfovibrio desulfuricans strains G20 (NC_007519) and Essex 6 (partial sequence; this study); D.a., Desulfobacterium autotrophicum (unpublished); D.p., Desulfotalea psychrophila (CR522870); G.s., Geobacter sulfurreducens (AE017180); W.s., W. succinogenes (CAE09943).

The (idealized) growth reactions $(\mathrm{a}, \mathrm{b})$ suggest that $D$. desulfuricans (Essex 6) uses about 70 to $80 \%$ of the fumarate for fumarate reduction when formate or $\mathrm{H}_{2}$ is present. Acetate production indicates oxidation of some fumarate.

$$
\begin{aligned}
& 1 \text { Fumarate }+0.8 \text { formate } \rightarrow 0.8 \text { succinate }+ \\
& 0.2 \text { acetate }+1.2 \mathrm{CO}_{2}
\end{aligned}
$$

1 Fumarate $+0.8 \mathrm{H}_{2} \rightarrow 0.8$ succinate +0.2 acetate +

$0.4 \mathrm{CO}_{2}$

\section{Fumarate disproportionation}

Fumarate supported growth of D. desulfuricans (Essex 6) and D. vulgaris also in the absence of formate or $\mathrm{H}_{2}$ (Fig. 3). Growth was slower than by fumarate respiration (Table 1), but for $D$. desulfuricans the final cell densities were comparable. The type of products changed depending on the growth phase (Fig. 3, Table 2). In the early growth phase of D. vulgaris most of the fumarate was converted to malate and small amounts of acetate. In the second phase, the production of acetate and succinate increased at the expense of malate. Overall, about two-thirds of the fumarate was excreted as succinate, the residue as acetate when malate is not considered (Table 2). Product formation from fumarate by $D$. desulfuricans was also biphasic, but the differences between the first phase with and the second phase without malate production were less pronounced. Malate production was much lower than for D. vulgaris (Fig. 3a). In the stationary phase about two-thirds of the fumarate was converted to succinate and one third to acetate (Table 2).

Fumarate disproportionation was studied in cell suspensions for a more detailed analysis (Table 3 ). In the early phase, D. vulgaris excreted mainly malate. In the second phase succinate was the major product and acetate the only further product. $D$. desulfuricans converted fumarate at much higher rates than $D$. vulgaris. Succinate and acetate were the main products, with small amounts of malate. In the late phase only succinate and acetate were produced, in an approximate ratio of $2: 1$. Malate seems to be an intermediate of fumarate fermentation and accumulates in the early phase due to limitation in subsequent metabolic steps. 

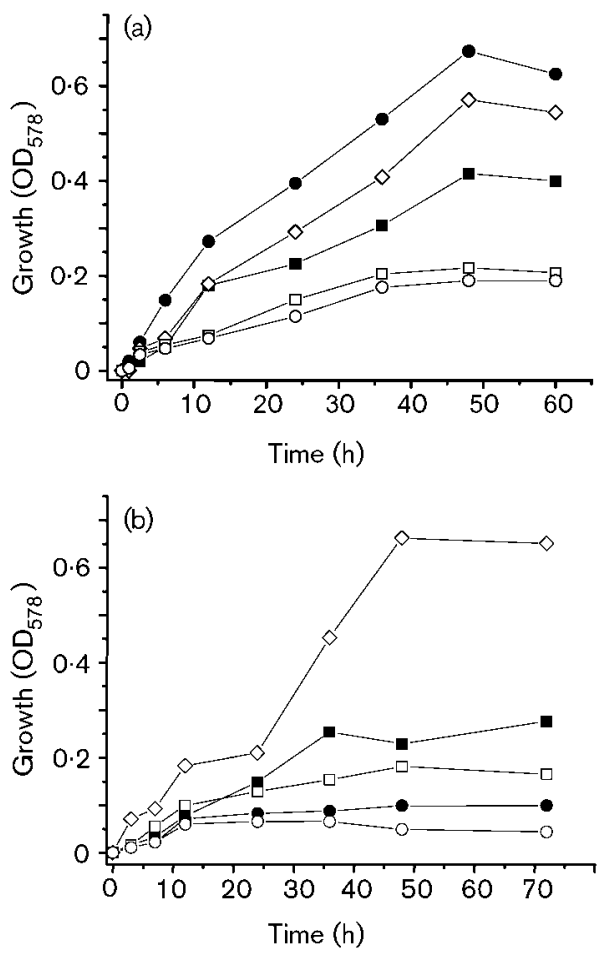

Fig. 2. Growth of $D$. desulfuricans (strain Essex 6) (a) and $D$. vulgaris (b) on fumarate (filled symbols) and sulphate (open symbols). Growth was performed under anoxic conditions in modified medium 63 containing $\mathrm{H}_{2}$ +fumarate $(\bullet)$, formate + fumarate $(\square)$, succinate + sulphate $(\square)$, lactate + sulphate $(\diamond)$ and sulphate $(\bigcirc)$ as the substrates for growth.

The limitation was significant in D. vulgaris and in cell suspensions.

\section{Succinate: menaquinone reductase from $D$. vulgaris requires $\Delta \mathrm{p}$ for function}

Cell-free extracts of D. desulfuricans (Essex 6) and D. vulgaris were tested for fumarate reductase and succinate dehydrogenase activities with artificial electron donors or acceptors (Table 4). The activities of D. vulgaris were low and showed only a small variation (factor $<3$ ) after growth by fumarate
Table 2. Fermentation reactions and products for growth of $D$. desulfuricans (strain Essex 6) and D. vulgaris on fumarate

In all experiments $>38 \mathrm{mM}$ fumarate was metabolized. $\mathrm{CO}_{2}$ formation was calculated by assuming that formate oxidation provides $1 \mathrm{CO}_{2}$ /formate and oxidation of fumarate $2 \mathrm{CO}_{2} /$ fumarate. For growth on $\mathrm{H}_{2}+$ fumarate it is assumed that $1 \mathrm{H}_{2}$ is consumed per succinate formed, and that $4[\mathrm{H}]$ are formed per acetate produced (see Fig. 5).

\begin{tabular}{|c|c|c|c|c|c|}
\hline \multirow[t]{2}{*}{ Substrates } & \multicolumn{4}{|c|}{$\begin{array}{l}\text { Products [mol (mol } \\
\left.\text { fumarate })^{-1}\right]\end{array}$} & \multirow[t]{2}{*}{$\% \mathrm{C}$} \\
\hline & Succ & Mal & Acetate & $\mathrm{CO}_{2}$ & \\
\hline \multicolumn{6}{|l|}{ D. desulfuricans } \\
\hline $\begin{array}{l}1 \text { Fumarate }+0.69 \\
\text { formate }\end{array}$ & $0 \cdot 91$ & $<0 \cdot 02$ & $0 \cdot 24$ & $1 \cdot 17$ & 112 \\
\hline 1 Fumarate $+0.54 \mathrm{H}_{2}$ & $0 \cdot 84$ & $<0 \cdot 02$ & $0 \cdot 15$ & $0 \cdot 30$ & 99 \\
\hline 1 Fumarate $^{\star}$ & $0 \cdot 67$ & $<0 \cdot 02$ & $0 \cdot 37$ & $0 \cdot 74$ & 105 \\
\hline \multicolumn{6}{|l|}{ D. vulgaris } \\
\hline 1 Fumarate $\dagger \ddagger$ & $<0.02$ & $0 \cdot 85$ & $0 \cdot 13$ & $0 \cdot 26$ & 163 \\
\hline 1 Fumarate $^{\star}$ & $0 \cdot 55$ & $0 \cdot 33$ & $0 \cdot 27$ & $0 \cdot 54$ & 115 \\
\hline
\end{tabular}

${ }^{\star}$ Stationary growth phase.

$\dagger$ Early growth phase.

¥In addition formate was excreted.

or sulphate respiration, or in the presence of succinate. Fumarate reductase activities of $D$. desulfuricans were two orders of magnitude higher than those of D. vulgaris, and also showed no strong variation in response to the growth substrates. The ratio of fumarate reductase vs succinate dehydrogenase activities was significantly higher for $D$. desulfuricans than for $D$. vulgaris (mean value 25 versus 4 ), suggesting that the enzyme of $D$. desulfuricans resembles a fumarate reductase, and that of $D$. vulgaris a succinate dehydrogenase.

Intact cells of $D$. vulgaris were capable of menaquinone reduction by succinate (Fig. 4, Table 5) after growth on sulphate or fumarate. DMN is very similar to menaquinone in structure and midpoint potential $\left(\mathrm{E}_{0}^{\prime}=-80 \mathrm{mV}\right)$ and

Table 1. Growth parameters of $D$. desulfuricans (strain Essex 6) for growth on fumarate and sulphate

\begin{tabular}{|llccc|}
\hline Condition & $\begin{array}{c}\boldsymbol{\mu} \\
\left(\mathbf{h}^{\mathbf{- 1}}\right)\end{array}$ & $\begin{array}{c}\boldsymbol{\Delta} \text { Fumarate } \\
(\mathbf{m M})\end{array}$ & $\begin{array}{c}\text { Cell mass } \\
\left(\mathbf{g ~ d w ~}^{\mathbf{- 1}}\right)\end{array}$ & $\begin{array}{c}\boldsymbol{Y}_{\text {Fum }} \text { [g dw } \\
(\mathbf{m o l ~ F u m})^{-\mathbf{1}}\end{array}$ \\
\hline Formate + fumarate & $0 \cdot 09$ & 39 & 192 & $4 \cdot 9$ \\
$\mathrm{H}_{2}+$ fumarate & $0 \cdot 16$ & 41 & 198 & $4 \cdot 8$ \\
Fumarate & $0 \cdot 1$ & 42 & 170 & $3 \cdot 9$ \\
Lactate + sulphate & $0 \cdot 14$ & NA & NA & NA \\
\hline
\end{tabular}

NA, Not applicable.

${ }^{\star}$ Fumarate consumption. 

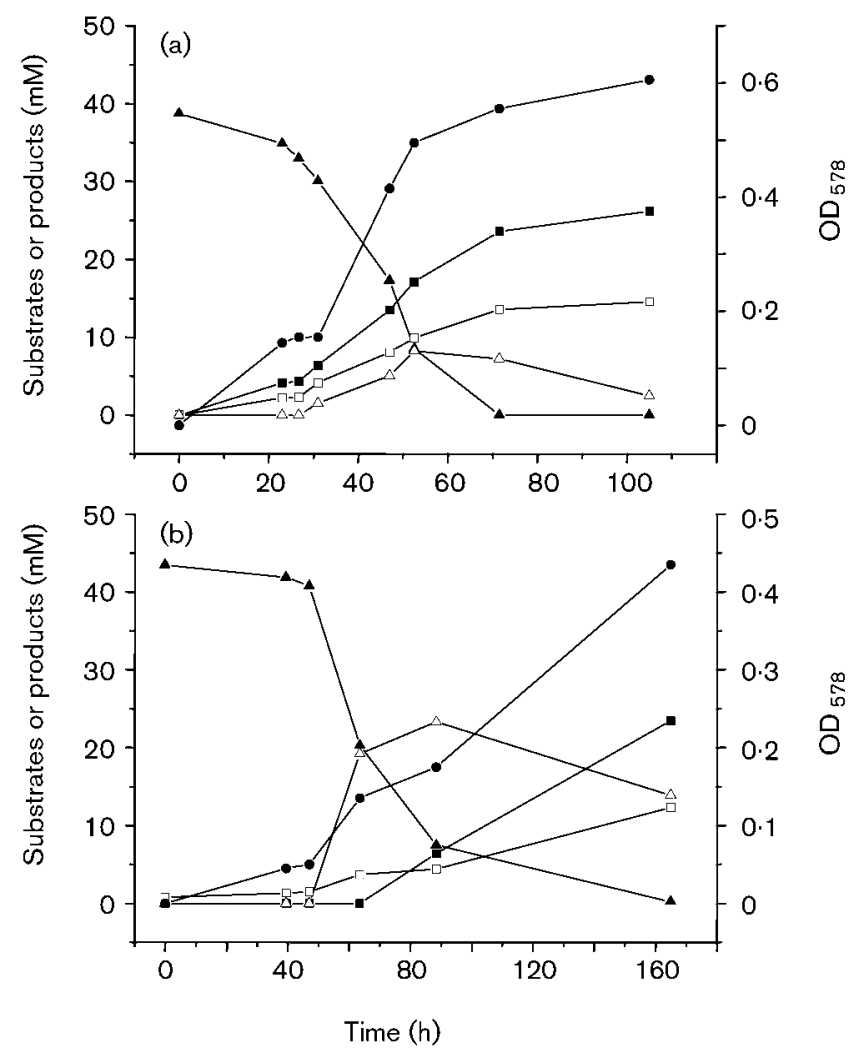

Fig. 3. Growth of $D$. desulfuricans (strain Essex 6) (a) and of $D$. vulgaris (b) on fumarate, and excretion of malate, succinate and acetate. The bacteria were grown $\left(\boldsymbol{O}, \mathrm{OD}_{578}\right)$ in modified medium 63 with $50 \mathrm{mM}$ fumarate. Fumarate $(\boldsymbol{\Lambda})$ and the end products [succinate $(\boldsymbol{\square})$, malate $(\triangle)$ and acetate $(\square)$ ] were determined in the supernatant by HPLC.

can be used as a water-soluble analogue of menaquinone. The activity with DMN was lost after addition of the uncoupler CCCP to the bacterial cells (Fig. 4, Table 5), or breaking the cells and preparing cell homogenates (Table 5), presumably due to dissipation of the proton potential, which was shown earlier as the driving force for DMN (or menaquinone) : succinate oxidoreductase in B. subtilis and other Gram-positive bacteria (Schirawski \& Unden, 1998; Schnorpfeil et al., 2001). In contrast, high activity of succinate dehydrogenase with the artificial electron acceptor DCPIP was retained in the cell homogenate $[75 \mathrm{U}$ (g protein $)^{-1}$. It is concluded that this activity is, in contrast to succinate: DMN reductase, not sensitive to breaking the cell membrane.

D. desulfuricans (Essex 6) showed similar activities of DMN reduction by succinate as $D$. vulgaris, and the activity was also sensitive to the presence of uncoupler (not shown). Due to unstable activities the response to the uncoupler was not studied in detail. Future experiments will have to show whether the Sdh/Frd enzymes of other sulphate-reducing bacteria respond in the same way to uncoupler and membrane disintegration as in $D$. vulgaris.

\section{DISCUSSION}

\section{Fumarate respiration and disproportionation by sulphate-reducing bacteria}

All sulphate-reducing bacteria with known genome sequences (or drafts) contain one set of genes for succinate: quinone oxidoreductases of the FrdABC/SdhABCtype. In $D$. desulfuricans (strain Essex 6), the enzyme functions as fumarate reductase and the bacteria are able to grow by fumarate respiration or by fumarate disproportionation. Fumarate respiration and fumarate reductase have also been demonstrated for Desulfovibrio gigas and Desulfovibrio multispirans (Odom \& Peck, 1981; He et al., 1986; Lemos et al., 2002), for which, however, no genome, gene or protein sequences are available. Fumarate reductase of the sulphate- and sulphur-reducing bacteria therefore is of the same type (FrdABC with two haem B groups in subunit C) as in other $\varepsilon$-proteobacteria (Lancaster \& Simon, 2002).

Fumarate disproportionation by the bacteria allows balanced growth by oxidation of $1 \mathrm{~mol}$ fumarate to acetate

Table 3. Products of fumarate fermentation by cell suspensions of $D$. desulfuricans (Essex 6 ) and $D$. vulgaris

Cell suspensions $\left(\mathrm{OD}_{578}\right.$ 8-9; OD 1 corresponds to $300 \mathrm{mg}$ dry weight $\mathrm{l}^{-1}$ ) of the bacteria were incubated with $5 \mathrm{mM}$ fumarate under anoxic conditions for $60 \mathrm{~min}$ (D. desulfuricans) and $720 \mathrm{~min}$ (D. vulgaris). Substrates and products were determined by HPLC for the indicated periods of time; the product concentrations shown represent the difference between the beginning and the end of the respective period.

\begin{tabular}{|c|c|c|c|c|c|c|c|}
\hline \multirow[t]{2}{*}{ Bacterium } & \multirow{2}{*}{$\begin{array}{l}\text { Time } \\
(\min )\end{array}$} & \multirow{2}{*}{$\begin{array}{c}\text { Turnover } \\
{\left[\mathbf{U}(\mathbf{g ~ d w})^{-1}\right]}\end{array}$} & \multicolumn{4}{|c|}{ Products [mol (mol fumarate $\left.)^{-1}\right]$} & \multirow[t]{2}{*}{$\% \mathrm{C}$} \\
\hline & & & Succinate & Malate & Acetate & $\mathrm{CO}_{2}$ & \\
\hline D. vulgaris & $480-720$ & $5 \cdot 3$ & $0 \cdot 77$ & 0 & $0 \cdot 41$ & $0 \cdot 82$ & 117 \\
\hline D. desulfuricans & $0-30$ & $46 \cdot 5$ & $0 \cdot 59$ & $0 \cdot 21$ & $0 \cdot 41$ & $0 \cdot 82$ & 121 \\
\hline
\end{tabular}


Table 4. Fumarate and succinate dehydrogenase activities of $D$. desulfuricans (strain Essex 6) and $D$. vulgaris on various substrates

Specific activities were measured in cell-free homogenates under anoxic conditions with BV or DCPIP. One unit $(\mathrm{U})$ corresponds to the consumption of $1 \mu \mathrm{mol}$ fumarate or succinate $\min ^{-1}$ (g protein $)^{-1}$.

\begin{tabular}{|lcccc|}
\hline Bacterium & Growth & BV $\rightarrow$ Fum $(\mathbf{U})$ & Succ $\rightarrow$ DCPIP $(\mathbf{U})$ & Frd/Sdh activity \\
\hline D. vulgaris & Lactate + sulphate & 117 & 31 & $3 \cdot 8$ \\
& Formate + fumarate & 77 & 38 & $2 \cdot 0$ \\
& Succinate + sulphate & 193 & 30 & $6 \cdot 4$ \\
D. desulfuricans & Lactate + sulphate & 13690 & 385 & 36 \\
& Formate + fumarate & 7770 & 449 & 23 \\
& Lactate + sulphate & 10297 & 452 & 23 \\
& & & & \\
\hline
\end{tabular}

and reduction of $2 \mathrm{~mol}$ fumarate to succinate (reaction (c)) (Fig. 5). The $[\mathrm{H}]$ for succinate production is derived from pyruvate oxidation $\left(\mathrm{Fd}_{\text {red }}, \mathrm{H}_{2}\right.$ or formate).

3 Fumarate $\rightarrow 2$ succinate $+2 \mathrm{CO}_{2}+$ acetate

The structural genes for the enzymes of the pathway are found in the genomes of $D$. desulfuricans $\mathrm{G} 20$ and D. vulgaris (Fig. 5) (www.jgi.doe.gov; www.tigr.org/), and presumably also in D. desulfuricans (strain Essex 6) due to the similar fermentation pattern. Malic enzyme, fumarase and acetate kinase were demonstrated also by their enzymic activities (Lewis \& Miller, 1977; Brown \& Akagi, 1966). Malate, which was suggested earlier as a product of fumarate disproportionation (Miller \& Wakerley, 1966), apparently is only an intermediate. A similar form of fumarate disproportionation with succinate, acetate and $\mathrm{CO}_{2}$ as the products was described for Clostridium formicoaceticum (Dorn et al., 1978), whereas fumarate disproportionation by Proteus

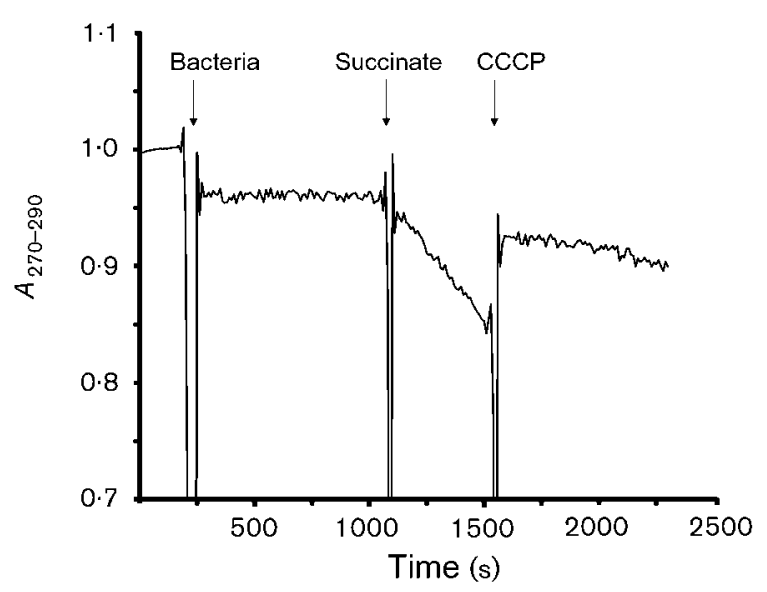

Fig. 4. Succinate: $D M N$ reductase activity of $D$. vulgaris and effect of the uncoupler CCCP. The activity (DMN reduction by succinate) was measured with cells of the bacteria $(6.5 \mathrm{mg}$ protein $\mathrm{ml}^{-1}$ ) by recording the reduction of DMN spectroscopically at $270 \mathrm{~nm}$ and $290 \mathrm{~nm}$ (reference wavelength). CCCP (arrow) was added at $10 \mu \mathrm{M}$. rettgeri produced only succinate but no acetate (Kröger, 1974).

\section{Succinate : menaquinone reductase of $D$. vulgaris: a reversed redox loop mechanism}

The succinate: quinone oxidoreductase of $D$. vulgaris is a succinate dehydrogenase due to the lack of fumarate respiration and the high ratio of Sdh/Frd activity. D. vulgaris is not capable of complete oxidation of organic matter (Postgate, 1984) and does not encode all enzymes of the citric acid cycle and of related pathways (www.jgi.doe.gov; http://www. genome.jp/kegg/; www.tigr.org/; http://www.microbesonline. org/). Therefore succinate dehydrogenase activity might be important for specific metabolic reactions, but not for degradation of citric acid cycle intermediates, which would explain their poor growth on succinate. The sensitivity of succinate:DMN (but not succinate:DCPIP) reductase activity of $D$. vulgaris to dissipation of the proton potential is reminiscent of succinate dehydrogenase of $B$. subtilis and other aerobic Gram-positive bacteria (Schirawski \& Unden, 1998). Therefore the need for a proton potential is common

Table 5. Specific activities of succinate: DMN reductase in cells of $D$. desulfuricans (Essex 6 ) and $D$. vulgaris, and response to the uncoupler $\operatorname{CCCP}(10 \mu \mathrm{M})$ and to cell disintegration (cell homogenate preparation)

The bacteria were grown in modified medium M63 with $50 \mathrm{mM}$ formate $+50 \mathrm{mM}$ fumarate. Similar activities were measured after growth of the bacteria on lactate + sulphate ( $D$. desulfuricans) or succinate + sulphate $(D$. vulgaris $)$. One unit corresponds to the consumption of $1 \mu \mathrm{mol}$ succinate $\min ^{-1}$ (g protein $)^{-1}$.

\begin{tabular}{|llc|}
\hline Bacterium & Preparation & Suc $\rightarrow$ DMN (U) \\
\hline D. vulgaris & Cells & $15 \cdot 3$ \\
& Cells + CCCP & $1 \cdot 4$ \\
& Cell homogenate & $1 \cdot 0$ \\
D. desulfuricans & Cells & $19 \cdot 2$ \\
& Cells + CCCP & $0 \cdot 3$ \\
& Cell homogenate & $<0 \cdot 5$ \\
\hline
\end{tabular}



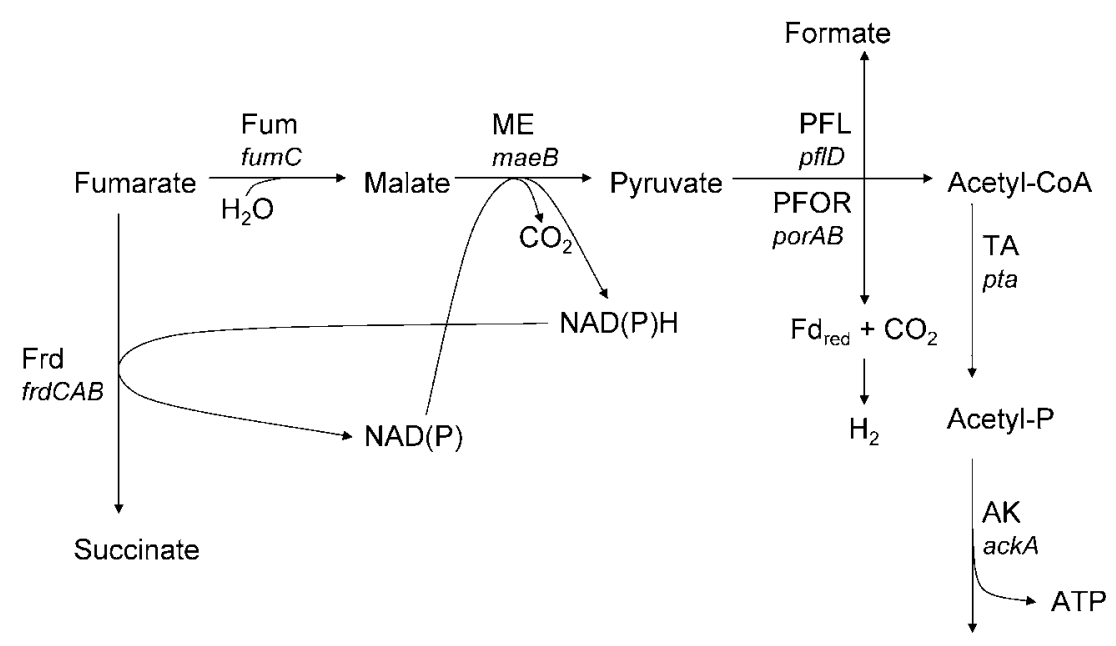

Acetate
Fig. 5. Fermentation pathways for fumarate disproportionation by suphate-reducing bacteria. The pathway shows the oxidation of fumarate to acetate and the reduction of fumarate to succinate. Fumarate oxidation supplies $\mathrm{NAD}(\mathrm{P}) \mathrm{H}$ and reduced ferredoxin/ $\mathrm{H}_{2}$ (or formate), which are reoxidized by two molecules of fumarate (fermentation balance: 3 Fum $\rightarrow 1$ acetate +2 succinate $\left.+2 \mathrm{CO}_{2}\right)$. to menaquinone-dependent succinate dehydrogenases from aerobic Gram-positive and anaerobic Gram-negative bacteria. The same type of succinate dehydrogenase (SdhABC), the His ligands for transmembrane arrangement of two haem B groups and the conserved Glu residue of the external menaquinone site suggest that these phylogentically and physiologically different bacteria use the same principle of a reverse redox loop mechanism to drive the reduction of menaquinone by succinate. Enzymes with an established structure constituting a redox loop are represented by formate dehydrogenase and nitrate reductase from $E$. coli (Jormakka et al., 2002, 2003). Both enzymes generate $\Delta \mathrm{p}$ by the release of $\mathrm{H}^{+}$at the periplasmic side of the membrane during oxidation of one substrate and consumption of $\mathrm{H}^{+}$ in the cytoplasm during reduction of the second substrate.

\section{General presence of the 'E-pathway' in fumarate reductases of the FrdABC type?}

Fumarate reductase from $W$. succinogenes shows a transmembrane arrangement of the two haem $B$ groups in FrdC (Körtner et al., 1990; Gross et al., 1998; Lancaster et al., 1999). The enzyme, however, does not generate a proton potential by menaquinol: fumarate reduction (Biel et al., 2002; Kröger et al., 2002). Glu180 in transmembrane helix IV of $W$. succinogenes FrdC is part of a $\mathrm{H}^{+}$shortcut ('Epathway') which dissipates the proton potential generated by fumarate reductase (Lancaster, 2002a; Lancaster et al., 2005; Haas et al., 2005). Glu180 is conserved in the enzyme of $D$. desulfuricans G20 (and of D. autotrophicum), which is in agreement with the function of the enzyme as fumarate reductases. The enzyme from $D$. vulgaris (and similarly those from B. subtilis, G. sulfurreducens and Desulfotalea psychrophila) lacks the 'uncoupling' Glu180 residue, which is in accordance with their role as a 'coupling' succinate dehydrogenase.

D. desulfuricans (strain Essex 6), which was used for the biochemical and physiological experiments, is not closely related to strain G20 (Pires, et al. 2003), which is reflected by the different sequences of the FrdC subunits. FrdC of strain Essex 6 lacks the Glu180 homologue, which is in agreement with the $\Delta \mathrm{p}$-dependence of succinate : DMN oxidoreductase activity as determined experimentally. Further experiments will have to show how these properties are compatible with the physiological function of the enzyme of strain Essex 6 in fumarate respiration.

\section{Lack of DcuB-type fumarate/succinate antiporter in $D$. desulfuricans}

The genome of $D$. desulfuricans $\mathrm{G} 20$ contains no genes for anaerobic fumarate/succinate antiporters DcuB, DcuA or DcuC (Engel et al., 1994; Six et al., 1994; Zientz et al., 1999; Janausch et al., 2002; Golby et al., 1998; Unden \& Kleefeld, 2004). DcuB catalyses electroneutral fumarate/succinate antiport. DcuB is typical for bacteria growing by fumarate respiration and can be replaced by the homologues DcuA and DcuC.

D. desulfuricans contains genes for five putative periplasmic solute-binding proteins, four of which are clustered with homologues of the $d c t Q$ and/or $d c t M$ genes encoding membrane-bound components of TRAP carriers (tripartite ATP-independent periplasmic carriers). In D. vulgaris, genes for three solute-binding proteins and homologues of $d c t Q$ and $d c t M$ genes are found. TRAP transporters represent secondary carriers which are driven by $\mathrm{a} \mathrm{H}^{+}$gradient and use a periplasmic binding protein to recruit the solute (Kelly \& Thomas, 2001; Forward et al., 1997). Using CLUSTAL $\mathrm{X}$-aligned sequences and PHYLIP analysis the solute-binding proteins of TRAP transporters have been used for constructing a phylogenetic tree, which showed clustering of $\mathrm{C}_{4}$-dicarboxylate-binding proteins (Thomas et al., 2006). By the same method the DctP homologues of $D$. desulfuricans and $D$. vulgaris were used to construct an unrooted bootstrapped tree with sequences from those TRAP binding proteins, where biochemical evidence for the identity of the 


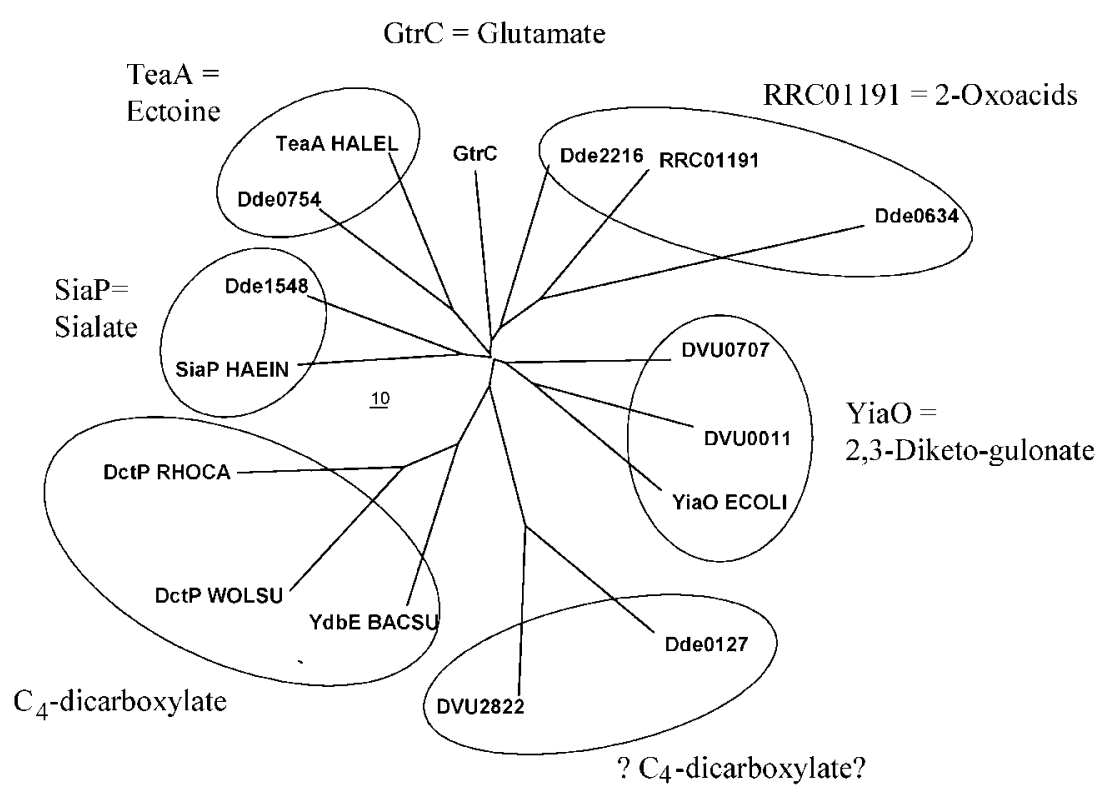

Fig. 6. Unrooted bootstrapped tree of the DctP homologues from $D$. desulfuricans G20 (Dde proteins) and D. vulgaris (DVU proteins). The tree was obtained by analysis of the CLUSTAL $X$ aligned sequences by PHYLIP and is shown in TREEVIEW. As reference proteins, TRAP solute-binding proteins were used for which the ligands have previously been identified by biochemical analyses (for details see Kelly \& Thomas, 2001; Thomas et al., 2006). Proteins used: YdbE from Bacillus subtilis (YdbE BACSU), DctP from Wolinella succinogenes (DctP WOLSU), DctP from Rhodobacter capsulatus (DctP RHOCA), SiaP from Haemophilus influenzae (SiaP HAEIN), TeaA from Halomonas elongata (TeaA HALEL), GtrC from Synechocystis sp. (GtrC), RRC01191 from R. capsulatus (RRC01191) and $\mathrm{YiaO}$ from $E$. coli (YiaO). ligand bound is available (Fig. 6). The proteins of D. vulgaris and $D$. desulfuricans cluster into six distinct groups. The clustering is significant since the known $\mathrm{C}_{4}$-dicarboxylatebinding proteins from phylogenetically distinct bacteria cluster together. The $D$. vulgaris and $D$. desulfuricans proteins DVU2822 and Dde0127, respectively, are closely related to known $\mathrm{C}_{4}$-dicarboxylate-binding proteins, and are good candidates for $\mathrm{C}_{4}$-dicarboxylate-binding proteins. The other TRAP solute-binding proteins of $D$. desulfuricans and D. vulgaris cluster with binding proteins for 2,3diketogulonate, 2-oxoacids, ectoine or sialate (Fig. 6) (see Kelly \& Thomas, 2001; Severi et al., 2005; Thomas et al., 2006). W. succinogenes encodes a DctPQM TRAP carrier in addition to DcuB and DcuA. DctPQM catalysed fumarate uptake, but did not support growth by fumarate respiration (Ullmann et al., 2000). The TRAP carriers could be involved in $\mathrm{C}_{4}$-dicarboxylate uptake during aerobic growth, but in fumarate respiration the function of alternative secondary carriers is more likely. The genes Dde0326, 0693, 0808, 1204 and 1252 of $D$. desulfuricans encode secondary carriers similar to the di-/tricarboxylate carrier CitT or the $\mathrm{Na}^{+} / \mathrm{H}^{+}$ dicarboxylate symporter GltP (Pos et al., 1998; http:// www.jgi.doe.gov/). Carriers of the CitT family can be used for $\mathrm{C}_{4}$-dicarboxylate antiport $(\mathrm{O} . \mathrm{B} . \mathrm{Kim} \& \mathrm{G}$. Unden, unpublished). The glutamate carrier GltP (Tolner et al., 1995) is homologous to $\mathrm{C}_{4}$-dicarboxylate carriers and the homologues in the sulphate-reducing bacteria represent candidates for $\mathrm{C}_{4}$-dicarboxylate transport. The genome of D. vulgaris encodes carriers with similarity to malonate carriers (predicted protein DVU1401) or an oxalate/formate antiporter (DVU1163) (http://www.membranetransport. org). Thus both Desulfovibrio strains contain candidate genes different from the $d c u$ genes which could function in $\mathrm{C}_{4}$-dicarboxylate transport.

\section{ACKNOWLEDGEMENTS}

The work was supported by a grant from the Deutsche Forschungsgemeinschaft. We are grateful to Dr A. Strittmatter and Dr G. Gottschalk (Göttingen) for supplying sequences prior to publication, and Dr R. Lancaster (Frankfurt) for critical reading of the manuscript.

\section{REFERENCES}

Bernhard, T. \& Gottschalk, G. (1978). Cell yields of Escherichia coli during anaerobic growth on fumarate and molecular hydrogen. Arch Microbiol 116, 235-238.

Berriman, M. \& Rutherford, K. (2003). Viewing and annotating sequence data with Artemis. Brief Bioinform 4, 124-132.

Biel, S., Simon, J., Gross, R., Ruiz, T., Ruitenberg, M. \& Kröger, A. (2002). Reconstitution of coupled fumarate respiration in liposomes by incorporating the electron transport enzymes isolated from Wolinella succinogenes. Eur J Biochem 269, 1974-1983.

Bode, C. H., Goebell, H. \& Stähler, E. (1968). Zur Eliminierung von Trübungsfehlern bei der Eiweißbestimmung bei der Biuretmethode. Z Klin Chem Biochem 6, 418-422.

Bradford, M. M. (1976). A rapid and sensitive method for the quantitation of microgram quantities of protein using the principle of protein-dye binding. Anal Biochem 72, 248-254.

Brown, M. S. \& Akagi, J. M. (1966). Purification of acetokinase from Desulfovibrio desulfuricans. J Bacteriol 92, 1273-1274.

Cecchini, G., Schröder, I., Gunsalus, R. P. \& Maklashina, E. (2002). Succinate dehydrogenase and fumarate reductase from Escherichia coli. Biochim Biophys Acta 1553, 140-157.

Collins, M. D. \& Widdel, F. (1986). Respiratory quinones of sulphatereducing and sulphur-reducing bacteria: a systematic investigation. Syst Appl Microbiol 8, 8-18.

Dorn, M., Andreesen, J. R. \& Gottschalk, G. (1978). Fermentation of fumarate and L-malate by Clostridium formicoaceticum. J Bacteriol 133, 26-32. 
DSM (1993). Desulfovibrio medium, No 63. In Catalogue of Strains, p. 357. Braunschweig: Deutsche Sammlung von Mikroorganismen und Zellkulturen.

Engel, P., Krämer, R. \& Unden, G. (1994). Transport of $\mathrm{C}_{4^{-}}$ dicarboxylates by anaerobically grown Escherichia coli: energetics and mechanism of exchange, uptake and efflux. Eur J Biochem 222, 605-614.

Felsenstein, J. (1989). PHYLIP - Phylogeny Inference Package (Version 3.2). Cladistics 5, 164-166.

Forward, J. A., Behrendt, M. C., Wyborn, N. R., Cross, R. \& Kelly, D. J. (1997). TRAP transporters: a new family of periplasmic solute transport systems encoded by the dctPQM genes of Rhodobacter capsulatus and by homologs in diverse gram-negative bacteria. J Bacteriol 179, 5482-5493.

Golby, P., Kelly, D. J., Guest, J. R. \& Andrews, S. C. (1998). Transcriptional regulation and organization of the $d c u A$ and $d c u B$ genes, encoding homologous anaerobic $\mathrm{C}_{4}$ dicarboxylate transporters in Escherichia coli. J Bacteriol 180, 6586-6596.

Gross, R., Simon, J., Lancaster, C. R. \& Kröger, A. (1998). Identification of histidine residues in Wolinella succinogenes hydrogenase that are essential for menaquinone reduction by $\mathrm{H}_{2}$. Mol Microbiol 30, 639-646.

Haas, A. H., Sauer, U. S., Gross, R., Simon, J., Mäntele, W. \& Lancaster, C. R. (2005). FTIR difference spectra of Wolinella succinogenes quinol: fumarate reductase support a key role of Glu C180 within the 'E-pathway hypothesis'of coupled transmembrane electron and proton transfer. Biochemistry 40, 13949-13961.

Hägerhäll, C. (1997). Succinate : quinone oxidoreductases. Variations on a conserved theme. Biochim Biophys Acta 1320, 107-141.

Hägerhäll, C. \& Hederstedt, L. (1996). A structural model for the membrane-integral domain of succinate:quinone oxidoreductases. FEBS Lett 389, 25-31.

Hägerhäll, C., Friden, H., Aasa, R. \& Hederstedt, L. (1995). Transmembrane topology and axial ligands to hemes in the cytochrome $b$ subunit of Bacillus subtilis succinate:menaquinone reductase. Biochemistry 34, 11080-11089.

He, S. H., DerVartanian, D. V. \& LeGall, J. (1986). Isolation of fumarate reductase from Desulfovibrio multispirans, a sulfate reducing bacterium. Biochem Biophys Res Commun 135, 1000-1007.

Hederstedt, L. (2002). Succinate:quinone oxidoreductase in the bacteria Paracoccus denitrificans and Bacillus subtilis. Biochim Biophys Acta 1553, 74-83.

Janausch, I. G., Zientz, E., Tran, Q. H., Kröger, A. \& Unden, G. (2002). $C_{4}$-dicarboxylate carriers and sensors in bacteria. Biochim Biophys Acta (Rev Bioener) 1553, 39-56.

Jormakka, M., Tornroth, S., Byrne, B. \& Iwata, S. (2002). Molecular basis of proton motive force generation: structure of formate dehydrogenase-N. Science 295, 1863-1868.

Jormakka, M., Byrne, B. \& Iwata, S. (2003). Protonmotive force generation by a redox loop mechanism. FEBS Lett 545, 25-30.

Kelly, D. \& Thomas, G. H. (2001). The tripartite ATP-independent periplasmic (TRAP) transporters of bacteria and archaea. FEMS Microbiol Rev 25, 405-424.

Kröger, A. (1974). Electron transport phosphorylation coupled to fumarate reduction in anaerobically grown Proteus rettgeri. Biochim Biophys Acta 347, 273-289.

Kröger, A., Biel, S., Simon, J., Gross, R., Unden, G. \& Lancaster, C. R. D. (2002). Fumarate respiration of Wolinella succinogenes: enzymology, energetics, and coupling mechanism. Biochim Biophys Acta (Rev Bioener) 1553, 23-38.

Körtner, C., Lauterbach, F., Tripier, D., Unden, G. \& Kröger, A. (1990). Wolinella succinogenes fumarate reductase contains a dihaem cytochrome b. Mol Microbiol 4, 855-860.
Lancaster, C. R. (2002a). Wolinella succinogenes quinol:fumarate reductase- $2 \cdot 2 \AA$ resolution crystal structure and the E-pathway hypothesis of coupled transmembrane proton and electron transfer. Biochim Biophys Acta 1565, 215-231.

Lancaster, C. R. D. (2002b). Succinate : quinone oxidoreductases: an overview. Biochim Biophys Acta 1553, 1-6.

Lancaster, C. D. R. \& Simon, J. (2002). Succinate: quinone oxidoreductases from $\varepsilon$-proteobacteria. Biochim Biophys Acta 1553, 84-101. Lancaster, C. R., Kröger, A., Auer, M. \& Michel, H. (1999). Structure of fumarate reductase from Wolinella succinogenes at $2 \cdot 2 \AA$ resolution. Nature 402, 377-385.

Lancaster, C. R., Gross, R., Haas, A., Ritter, M., Mäntele, W., Simon, J. \& Kröger, A. (2000). Essential role of Glu-C66 for menaquinol oxidation indicates transmembrane electrochemical potential generation by Wolinella succinoogenes fumarate reductase. Proc Natl Acad Sci U S A 97, 13051-13056.

Lancaster, C. R. D., Sauer, U. S., Gross, R., Haas, A. H., Graf, J., Schwalbe, H., Mäntele, W., Simon, J. \& Madej, M. G. (2005). Experimental support for the 'E-pathway hypothesis' of coupled transmembrane $\mathrm{e}^{-}$and $\mathrm{H}^{+}$transfer in dihemic quinol:fumarate reductase. Proc Natl Acad Sci U S A 102, 18860-18865.

Lemma, E., Unden, G. \& Kröger, A. (1990). Menaquinone is an obligatory component of the chain catalyzing succinate respiration in Bacillus subtilis. Arch Microbiol 155, 62-67.

Lemos, R. S., Gomes, C. M., LeGall, J., Xavier, A. V. \& Teixeira, M. (2002). The quinol:fumarate oxidoreductase from the sulphate reducing bacterium Desulfovibrio gigas: spectroscopic and redox studies. J Bioenerg Biomembr 34, 21-30.

Lewis, A. J. \& Miller, J. D. A. (1977). The tricarboxylic pathway in Desulfovibrio. Can J Microbiol 23, 916-921.

Mell, H., Bronder, M. \& Kröger, A. (1982). Cell yields of Vibrio succinogenes growing with formate and fumarate as sole carbon and energy sources in chemostat cultures. Arch Microbiol 131, 224-228.

Miller, J. D. A. \& Wakerley, D. S. (1966). Growth of sulphate-reducing bacteria by fumarate dismutation. J Gen Microbiol 43, 101-107.

Odom, J. M. \& Peck, H. D., Jr (1981). Localization of dehydrogenases, reductases, and electron transfer components in the sulfate-reducing bacterium Desulfovibrio gigas. J Bacteriol 147, 161-169.

Overbeek, R., Larsen, N., Walunas, T. \& 19 other authors (2003). The ERGO genome analysis and discovery system. Nucleic Acids Res 31, 164-171.

Page, R. D. (1996). TREEVIEW: an application to display phylogenetic trees on personal computers. Comput Appl Biosci 12, 357-358.

Pires, R. H., Lourenco, A. I., Morais, F., Teixeira, M., Xavier, A. V., Saraiva, L. M. \& Pereira, I. A. (2003). A novel membrane-bound respiratory complex from Desulfovibrio desulfuricans ATCC 27774. Biochim Biophys Acta 1605, 67-82.

Pos, K. M., Dimroth, P. \& Bott, M. (1998). The Escherichia coli citrate carrier CitT: a member of a novel eubacterial transporter family related to the 2-oxoglutarate/malate translocator from spinach chloroplasts. J Bacteriol 180, 4160-4165.

Postgate, J. R. (1984). Genus Desulfovibrio. In Bergey's Manual of Systematic Bacteriology, vol. 1, pp. 666-672. Edited by N. R. Krieg \& S. R. Holt. Baltimore: Williams \& Wilkins.

Richter, H., Vlad, D. \& Unden, G. (2001). Significance of pantothenate for glucose fermentation by Oenococcus oeni and for suppression of the erythritol and acetate production. Arch Microbiol 175, 26-31.

Schirawski, J. \& Unden, G. (1998). Menaquinone dependent succinate dehydrogenase of bacteria catalyzes reversed electron transport driven by the proton potential. Eur J Biochem 257, 210-215. 
Schnorpfeil, M., Janausch, I. G., Biel, S., Kröger, A., Unden, G. (2001). Generation of a proton potential by succinate dehydrogenase of Bacillus subtilis functioning as a fumarate reductase. Eur J Biochem 268, 3069-3074.

Severi, E., Randle, G., Kivlin, P., Whitfield, K., Young, R., Moxon, R., Kelly, D., Hood, D. \& Thomas, G. (2005). Sialic acid transport in Haemopohilus influenzae is essential for lipopolysaccharide sialylation and serum resistance and is dependent on a novel tripartite ATPindependent periplasmic transporter. Mol Microbiol 58, 1173-1185.

Simon, J., Gross, R., Ringel, M., Schmidt, E. \& Kröger, A. (1998). Deletion and site-directed mutagenesis of the Wolinella succinogenes fumarate reductase operon. Eur J Biochem 251, 418-426.

Six, S., Andrews, S. C., Unden, G. \& Guest, J. R. (1994). Escherichia coli possesses two homologous anaerobic $\mathrm{C}_{4}$-dicarboxylate membrane transporters (DcuA and DcuB) distinct from the aerobic dicarboxylate transport system (Dct). J Bacteriol 176, 6470-6478.

Thomas, G. H., Southworth, T., Leon-Kempis, M. R., Leech, A. \& Kelly, D. J. (2006). Novel ligands for the extracellular solute receptors of two bacterial TRAP transporters. Microbiology 152, 187-198.

Thompson, J. D., Gibson, T. J., Plewniak, F., Jeanmougin, F. \& Higgins, D. G. (1997). The CLUSTAL_X windows interface: flexible strategies for multiple sequence alignment aided by quality analysis tools. Nucleic Acids Res 25, 4876-4882.

Tolner, B., Ubbink-Kok, T., Poolman, B. \& Konings, W. N. (1995). Charcterization of the proton/glutamate symport protein of Bacillus subtilis and its functional expression in Escherichia coli. J Bacteriol 177, 2863-2869.

Ullmann, R., Gross, R., Simon, J., Unden, G. \& Kröger, A. (2000). Transport of $\mathrm{C}_{4}$-dicarboxylates in Wolinella succinogenes. J Bacteriol 182, 5757-5764.

Unden, G. \& Kleefeld, A. (2004). $\mathrm{C}_{4}$-dicarboxylate degradation in aerobic and anaerobic growth. In EcoSal - Escherichia coli and Salmonella: Cellular and Molecular Biology, chapter 3.4.5. Editor in Chief R. Curtiss, III. [Online: http://www.ecosal.org]. Washington, DC: American Society for Microbiology.

Unden, G., Hackenberg, H. \& Kröger, A. (1980). Isolation and functional aspects of the fumarate reductase involved in phosphorylative electron transport of Vibrio succinogenes. Biochim Biophys Acta 591, 275-288.

Zientz, E., Janausch, I. G., Six, S. \& Unden, G. (1999). Function of DcuC as the $\mathrm{C}_{4}$-dicarboxylate carrier during glucose fermentation by Escherichia coli. J Bacteriol 181, 3716-3720. 